\title{
Cooperation contracts between embedded firms
}

Citation for published version (APA):

Blumberg, B. F. (2001). Cooperation contracts between embedded firms. Organization Studies, 22, 825852. https://doi.org/10.1177/0170840601225004

Document status and date:

Published: 01/01/2001

DOI:

10.1177/0170840601225004

Document Version:

Publisher's PDF, also known as Version of record

\section{Please check the document version of this publication:}

- A submitted manuscript is the version of the article upon submission and before peer-review. There can be important differences between the submitted version and the official published version of record.

People interested in the research are advised to contact the author for the final version of the publication, or visit the DOI to the publisher's website.

- The final author version and the galley proof are versions of the publication after peer review.

- The final published version features the final layout of the paper including the volume, issue and page numbers.

Link to publication

\footnotetext{
General rights rights.

- You may freely distribute the URL identifying the publication in the public portal. please follow below link for the End User Agreement:

www.umlib.nl/taverne-license

Take down policy

If you believe that this document breaches copyright please contact us at:

repository@maastrichtuniversity.nl

providing details and we will investigate your claim.
}

Copyright and moral rights for the publications made accessible in the public portal are retained by the authors and/or other copyright owners and it is a condition of accessing publications that users recognise and abide by the legal requirements associated with these

- Users may download and print one copy of any publication from the public portal for the purpose of private study or research.

- You may not further distribute the material or use it for any profit-making activity or commercial gain

If the publication is distributed under the terms of Article $25 \mathrm{fa}$ of the Dutch Copyright Act, indicated by the "Taverne" license above, 


\title{
Cooperation Contracts between Embedded Firms*
}

\author{
Boris F. Blumberg
}

Boris Blumberg

Business

Investment

Research Centre,

University of

Maastricht,

The Netherlands
Organization

Studies

$2001,22 / 5$

825-852

(C) 2001 EGOS

0170-8406/01

$0022-0027 \$ 3.00$

\section{Abstract}

Successful inter-firm cooperations require that the participating partners mitigate potential opportunistic behaviour. Contractual commitments are one management mechanism to achieve stable mutual cooperation. However, the impossibility in designing complete, explicit and easily enforceable contracts restricts their efficacy as a management mechanism. Mechanisms based on the social embeddedness of the partners can form a viable alternative and compliment for contracts. Hence, the usage of contractual commitments is explained by combining transaction cost economic reasoning with arguments on the social embeddedness of economic transactions. Finally, the derived hypotheses are tested on a data-set of 92 cooperations within five Dutch multinationals.

Descriptors: commitments, cooperation, social embeddedness, transaction cost theory

\section{Introduction}

Fiercer competition on price and quality through accelerating technological development and increasing globalization require firms to redefine and reorganize their business activities. Concentration on core competences, business re-engineering, (un)friendly take-overs and fusions with other firms are management issues reflecting this reorientation process. Such internal reorientations shift the boundaries of a firm (Coase 1937) and thereby influence the relationships with suppliers and customers. Ideally, internal hierarchies fully control activities within a firm's boundaries while relations beyond these boundaries rely on the invisible hand of the market mechanism. However, the market mechanism only works efficiently if the conditions of a perfect market are met. Perfect markets are characterized by (1) homogeneous goods or services; (2) numerous identical suppliers and buyers; (3) complete information; and (4) complete reversibility, i.e., all resources and investments are deployable for other purposes at no costs (see, e.g., Henderson and Quandt 1980: 94-96). Clearly, many transactions with external relations will not meet even more relaxed forms of these conditions. Hence, relying purely on the market mechanism is not an appropriate strategy in many exchange transactions. Alternatives to pure market relations are inter-firm cooperations that combine characteristics of 
market and hierarchical relations. While earlier research regarded cooperation as a transitional, non-sustainable arrangement between organizations (Williamson 1975), more recent research acknowledges cooperation as a genuine institutional arrangement (Williamson 1985: 83).

\section{Advantages and Disadvantages of Cooperations}

Joining an inter-firm cooperation results in a partial loss of control over one's own resources and a partial gain of control over the partner's resources. Hence, joining a cooperation means having less control over more resources. The joint control over more resources facilitates the utilization of potential benefits arising from economies of scale, combining different types of resources and risk spreading (see, e.g., Contractor and Lorange 1988: 9; Grandori and Soda 1995: 185; Harrigan 1988; Powell 1987: 71). These benefits form an incentive to cooperate. Next to the advantages of cumulating and combining resources, potential problems arise from the shared control over joint resources, in that shared control offers each partner opportunities to behave opportunistically (Milgrom and Roberts 1992: Chapt. 2). The following three examples illustrate typical forms of opportunistic behaviour in inter-firm relationships.

1. The private use of confidential information. While suppliers fear that their know-how might leak to competitors via the buyer, the latter is worried about producing a new competitor. That happened to the US bike manufacturer Schwinn, that outsourced its frame manufacturing to the then unknown Taiwanese Giant Manufacturing. After learning how to make frames, Giant decided to become a bike manufacturer itself. Today, Giant is one of the world's largest bike manufacturers, while Schwinn's role in the market is marginal (Quinn and Hilmer 1994: 89).

2. Reduced efforts in joint tasks. An example of such free-rider behaviour is assigning the company's least productive employees to the cooperation. Holding back and delaying the release of relevant information from market research or R\&D is another example of this kind of opportunistic behaviour (Pucik 1988: 488-490).

3. Opportunistic exit from the relationship. This kind of opportunism accompanies asymmetric and delayed contributions to the joint effort. Further, changes in the environment or the firm's strategy may induce an opportunistic exit. Stafford (1994: 69) reports, for example, that a joint venture between Liz Claiborne and Avon failed after Avon acquired Perfumes Stern, another producer of luxury fragrances. After this acquisition, Liz Claiborne perceived Avon as a direct competitor and left the alliance, although Avon wanted to continue it.

To reap the benefits of cooperation, the partners must trust each other not to take advantage of dependencies and chances for opportunistic behaviour. However, trust does not come automatically. Rather, both partners have to implement mechanisms that mitigate opportunism and compensate for the lack of trust. 
The aim of this paper is to explain the usage of contractual commitments. I start with an analysis of the opportunism-reducing properties of contractual commitments. Recognizing the limits of contracts, I introduce the social embeddedness of firms. I progress with a discussion on the relation between social embeddedness and initial trust. Theoretical considerations based on transaction cost economics as well as arguments on the social embeddedness of firms are developed to derive hypotheses on the usage of contractual commitments. These hypotheses are finally tested on a rich data-set of 92 technology cooperations.

\section{Cooperation through Commitments and Trust}

Although forming a cooperation should be beneficial for both partners, inter-firm cooperations often fail, because every cooperation offers each partner opportunities and incentives to take one-sided advantage of the other. The situation resembles the structure of a prisoner's dilemma (see, e.g., Dixit and Nalebuff 1991; Rasmusen 1989). Characteristic of such dilemmas is that rational behaviour of the partners results in a Paretosub-optimal outcome. After all, mutual cooperation would have yielded higher rewards for each partner than the mutual non-cooperation of both partners. Incentives and opportunities for opportunism give rise to distrust. Firms have reasonable fears that partners will take advantage of monitoring problems and of their control over joint resources. Hence, achieving Pareto improvements requires the implementation of mechanisms that foster mutual cooperation. Such mechanisms should, on the one hand, sufficiently reduce the opportunities and incentives for opportunism and, on the other hand, compensate a firm's loss if opportunism nevertheless occurs (Buskens 1999: 130).

\section{Commitments}

Within transaction cost economics, credible commitments are seen as an efficient instrument for achieving mutual cooperation (Williamson 1983). Commitments mitigate opportunism through the following mechanisms: (1) shifting control to third parties, (2) restricting one's own set of behavioural alternatives, (3) balancing (partial) information asymmetries, and (4) modifying the costs and benefits associated with certain behaviour (Weesie and Raub 1996: 204-205). Parties who commit themselves to arbitration, in the case of a conflict, shift the control of the situation to third parties. Third parties do not have an incentive to behave unfairly towards either of the cooperating partners, so they are trustworthier. Further, secrecy agreements as well as exclusivity assurances, such as the guarantee not to enter the home market of the partner, are examples of commitments that restrict one's behavioural alternatives in such a way that opportunistic obstruction is unlikely. Information asymmetries are rebalanced if the more informed partner provides insights and information, such as giving unrestricted access 
to its factories and laboratories. Finally, commitments can reduce the incentive for opportunism by putting additional costs on such behaviour. Penalty clauses for delayed or poor performance are an example of such commitments. Moreover, such clauses compensate the partner's losses if opportunism occurs and thereby reduce the partner's cooperation risk (Snijders 1996: 26-30).

\section{Management Instruments}

\section{Contracts and Commitments}

One important and widely used commitment instrument is the contract. Contractual clauses enable both partners to commit each other to partial control by the partner (Chung 1995; Ghemawat 1991). Generally, the amount of shifted and shared control will increase with the number of contractual clauses. A small contract may only contain clauses about the division of tasks within the inter-firm cooperation, while large ones may include additional commitments regarding, for example, the procedure for joint evaluations or specific clauses about intellectual property. Complete, explicit and easily enforceable contracts entirely assure the mitigation of any opportunism potential. Yet, designing contracts with these properties is impossible, because the future is not fully predictable. In rapidly changing environments, in particular, the number of possible future situations exceeds the imaginative and cognitive capacity of firms (Hart 1987: 166). Furthermore, considering all, including even the least likely future outcomes, would be very costly, and therefore inefficient. Consequently, contracts will not cover every possible situation and are incomplete (Al-Najjar 1995: 434).

A common practice used to increase the completeness of contracts is the formulation of wide and more general clauses that are broadly applicable. An example of such a general clause is 'The parties agree to solve conflicts in the mutual interest of the cooperation. Furthermore, they will put their utmost efforts into reaching an agreement.' The example above can be applied to very different issues, such as disagreements on prices, accusations of private use of information, etc. However, broad applicability comes at the costs of low explicitness. The wider a clause, the more space there is for different interpretations. Moreover, explicitness is closely linked to contract enforceability. Enforceability becomes crucial if third parties such as courts or arbiters get involved (Kreps 1990). Contracts that are ambiguous with respect to the definition and consequences of non-compliance are hard to enforce.

Certainly, contracts are a suitable instrument in mitigating opportunism and enabling mutual cooperation between firms. However, incompleteness, inexplicitness, and non-enforceability limit contracts (Macaulay 1963). Furthermore, designing, implementing and executing satisfactory contracts is costly. Firms will attempt to minimize the costs in relation to the necessary 
opportunism mitigation. Hence, firms will thoroughly assess the situation to determine the amount of necessary commitments.

\section{Trust, Threats and Social Embeddedness}

Cooperation between two firms may fail or not even begin, because partners do not trust the other to cooperate if non-cooperative behaviour yields higher returns. Theoretical models predicting such mutual non-cooperative behaviour rely on the simplification of assumptions related to perfect markets. In this section, I will relax two assumptions by introducing the social embeddedness of firms: (1) firms are not anonymous actors and (2) they do not operate in isolation from other actors without a history and expectations about the future. Firms are recognizable and have good or bad reputations. High expenditures on marketing and public relations indicate that firms actively invest in getting and keeping a good name. Furthermore, firms are embedded in a network of relations with other parties (Granovetter 1985). Even stronger, they form such networks as a response to market failure (Burt 1983; Ouchi 1980). Social embeddedness reduces the necessity of contractual commitments through the emergence of initial trust and the availability of (implicit) threats. In particular, I assess the influence of previous and future relations and networks on the contractual management of inter-firm cooperations (for an overview on networks and inter-firm cooperation see, e.g. Oliver and Ebers 1998; Sobero and Schrader 1998; Grabher 1993; Nohria and Eccles 1992).

What are conditions for the emergence of trust? According to Blau (1964: 94), time is an important aspect of trust. Firms learn to trust each other over time. They experience that a partner does not take advantage of dependencies or constructively solves small conflicts. Next to this past-oriented aspect of trust, there is also a future-oriented one. A common future creates trust through the overriding consideration that one is going to meet again (Luhmann 1979). Firms expecting to interact again in the future will place initial trust in the partner, because they assume that the other will not abuse their trust and jeopardize future interactions (see Axelrod 1984). Trust does not only emerge through direct past and future contacts between firms, but also through indirect ties embedded in social networks (Casson 1997: 118-122). Firms can also base their initial trust on the experiences well-known others had with the partner. Hearing from one's bank or suppliers that an intended partner is a reliable and competent company increases the amount of initial trust a firm is willing to place in the partner. Networks not only spread information about trustworthy firms, but also about less trustworthy ones. Thus, firms with overlapping networks can build upon initial trust because dishonouring this initial trust would damage one's reputation and provoke negative reactions from other business partners (Raub and Weesie 1990). Finally, social networks offer access to alternative partners. If a firm knows alternative partners, it can switch easily from an opportunistic partner to another partner. Implicit threats to exit the relationship discipline the partner, because the long-term benefits of a continued relationship outweigh the short-term gains of opportunism. 
Table 1

Relation between

Kinds of Social

Embeddedness and Opportunismmitigating

Mechanisms

\begin{tabular}{lll}
\hline & Initial Trust & (Implicit) Threats \\
\hline Temporal embeddedness & $\begin{array}{l}\text { Previous relations allow } \\
\text { learning about the partner's } \\
\text { competencies and } \\
\text { trustworthiness. }\end{array}$ & $\begin{array}{l}\text { Retaliation opportunities in } \\
\text { future transactions. }\end{array}$ \\
Network embeddedness & $\begin{array}{l}\text { The network provides } \\
\text { information about the } \\
\text { partner's competencies and } \\
\text { trustworthiness. }\end{array}$ & $\begin{array}{l}\text { Network ties with alternative } \\
\text { partners facilitate exit threat. } \\
\text { Network ties with partners of } \\
\text { the partner facilitate voice } \\
\text { threats that can damage the } \\
\text { partner's reputation. }\end{array}$ \\
\hline
\end{tabular}

Past experience, future expectations and network embeddedness create initial trust and allow for implicit threats. Table 1 summarizes the relationships between social embeddedness and mechanisms that foster initial trust and thereby mitigate opportunism. First, initial trust emerges because socially embedded firms are better informed. In previous relations, the firm learned about the partner's competence and behavioural attitude. Further, firms that are strongly embedded in a dense network can contact other firms to obtain information about unknown partners and markets at lower costs than less embedded firms. Thus, one's own experience, and that of others, build up initial trust. It should be noted that what I labelled initial trust here is rather similar to Coleman's approach (1990) of trust as the probability that a trustee is trustworthy and Williamson's (1993) notion on calculative trust. Second, a common future and a strong network embeddedness create conditions favourable for placing implicit threats that can act as a substitute for contractual commitments. It is important to note that most threats are implicit, i.e. that one partner fears that the other has credible sanction opportunities or feasible alternatives and therefore adopts a cooperative attitude. Three kinds of threats are distinguished: (1) threats of direct retaliation (Conybeare 1989), (2) threats to exit the relationship and (3) the threat to exercise voice and ruin the partner's reputation (Hirschmann 1970). Threats (1) and (3) are feasible and credible, if there will be future transactions between the two partners. Credible exit threats require the additional availability of alternative partners or the capability to continue without a partner. Voice threats are only feasible if information about opportunistic behaviour is spread around, causing others to reconsider their current and future businesses with the partners. Thus, the active involvement of other firms is essential.

\section{The Use of Commitments to Manage Inter-firm Relations}

Contractual commitments come at certain costs. Hence, decisions concerning the use of commitments designed to mitigate opportunism are subject to cost efficiency considerations. A sufficient mitigation of the 
opportunism problem is a sine qua non condition of efficiency. The opportunism problem of an inter-firm cooperation can be described on three dimensions, namely, the volume of cooperation, relation-specific investments, and uncertainty (Williamson 1985: 52-61). The power of these three dimensions to explain contractual arrangements has been broadly supported by empirical evidence (for overviews of empirical studies, see Blumberg 1998: 42-50; Klein and Shelanski 1995).

Frequency is an obvious dimension of the problem potential of purchasing transactions, the classical research object of transaction cost economics, but volume is more appropriate for the investigation of inter-firm cooperation, where the meaning of frequency is less clear. Williamson (1985: 60) argues, 'The costs of specialized governance structures will be easier to recover from large transactions of a recurring kind [emphasis added]'. Given that the frequency of technology cooperations does not vary much, the focus of the analysis is the volume of the cooperation. Furthermore, earlier empirical studies support the usefulness of considering volume in the analysis (John and Weitz 1988: 342-343; Leffler and Rucker 1991: 1077). The volume of a cooperation describes the amount of money that is at stake. The larger a cooperation is in financial terms, the more can be gained by opportunistic behaviour and the greater the damage the other can suffer. The outcome of a joint project that requires an input of 10 man-years is on average more valuable than outcomes resulting from an effort of one man-year. Analogously, a firm's interest in mitigating opportunism increases with the potential damage that the firm can suffer. Therefore contracts for larger cooperations contain more commitments.

\section{Hypothesis 1: The larger the volumes of a cooperation, the more contrac- tual commitments are used.}

Relation-specific investments are investments made by the partners, which are (partially) worthless outside the cooperation. Williamson (1985: 95-96) distinguishes four kinds of specificity: location specificity, specific assets, dedicated assets and human capital. Here, the first three are bundled into physical capital. Previous studies have found a positive relationship between specific investments in physical capital and contracting (Joskow 1985: 38; Palay 1985: 172-173; Palay 1984: 287). Next to the physical and human capital, I also include investments in social capital (Coleman 1988; Flap 1988). Typical examples of specific physical investments are specific machinery and capacity extensions that only pay off if the relation with the partner continues until, at least, break-even is reached. The training of one's employees in the partner's production processes is an example of specific investments in human capital. Building up a good understanding with a partner requires investments in social capital, such as, frequent business visits and invitations.

Relation-specific investments are a double-edged sword. On the one hand, relation-specific investments increase the investor's dependency on the other, and thereby reduce the investor's own incentives to behave oppor- 
tunistically, so that fewer contractual commitments are needed. On the other hand, the investing partner becomes more vulnerable, because the noninvesting partner can claim the quasi-rent of the specific investment (see, e.g., Klein et al. 1978; Milgrom and Roberts 1992; Richter and Furubotn 1996). Hence, the investing partner will protect the quasi-rent of his specific investments by asking for more commitments. Relation-specific investments create dependencies and complicate contractual relations (Williamson 1991: 282). Thus, cooperations requiring such specific investments will fail unless appropriate safeguards are implemented. Putting the emphasis on appropriate safeguards modifies the argument that one-sided relationspecific investments increase the incentives for opportunism, while mutual specific investments reduce the incentives. Relation-specific investments of firm B are often not an appropriate safeguard to protect the quasi-rent of specific investments of firm A. In the first place, asset specificity of investments can change over time. For example, the specificity of a custom-made new innovative product decreases when the innovation diffuses and new applications are developed. A decreasing specificity of investments evaporates the safeguard function. Second, it is often difficult to distinguish whether investments made in physical and human capital are relation or project-specific. If they are project-specific, a firm can re-use them in a relation with a new partner. Third, in cooperations that involve more than two firms, e.g. three firms, specific investments are a bad safeguard, if two of them decide to exclude the third firm. Given these considerations, my argument is that the absolute magnitude of relation-specific investment matters much more than differences in such investments between the partners.

Hypothesis 2: The higher the relation-specific investments within a cooperation, the more contractual commitments are used.

Uncertainty is the last dimension of the problem potential. Previous results concerning the relationship between uncertainty and contracting for interfirm relations are ambiguous. Walker and Weber (1984) as well as Levy (1985) found a positive relation, while Harrigan (1986) states a negative one. These ambiguous results are partly caused by the vagueness of the concept uncertainty resulting in different operationalizations. Consequently, Klein et al. (1990) suggest distinguishing different forms of uncertainty. Following Durkheim (1893: book I, Chapter 7), two kinds of uncertainty can be distinguished, namely external and internal uncertainty. External uncertainty refers to technological developments and changes in the market, such as the entry of new competitors or price adjustments. A high external uncertainty impedes the monitoring of the partner's performance, because opportunistic conduct is much harder to distinguish from force majeure. Consequently, high external uncertainty requires more commitments, because each partner can take advantage of the other's monitoring problem. A low level of expertise in a firm usually causes internal uncertainty. A low expertise level results in low monitoring capabilities, which 
can be exploited by the partner (Anderson 1988; Williamson 1985). Relations with suppliers of information technology are often characterized by asymmetries in the relevant expertise. Contractual commitments can compensate for disadvantages that arise from information asymmetries.

\section{Hypothesis 3: The higher the external and internal uncertainties of a coop- eration, the more contractual commitments are used.}

While the use of contractual instruments is easily observable, the reliance on mechanisms based on social embeddedness is not. First, a direct comparative assessment of the initial trust in the partner's competencies and behavioural attitudes is unfeasible. Second, one cannot directly observe implicit threats, only the conditions that favour the availability of such threats. Therefore, I did not investigate the use of mechanisms based on social embeddedness directly. Rather, cost-efficient management is assumed, i.e., a firm will minimize its relation management costs, given the required level of opportunism mitigation. Hence, factors influencing the costs associated with certain mechanisms should be investigated. Initial trust and implicit threats are inexpensive substitutes for contracting, if a firm is strongly embedded (Barney and Hansen 1994: 178). In the following section, I consider different aspects of temporal and network embeddedness. As mentioned before, temporal embeddedness is split into the backward-oriented 'shadow of the past' and the forward-oriented 'shadow of the future'. Within network embeddedness, voice networks can be distinguished from exit networks. The former refers to the access to information and the ability to spread information, while the latter points to the alternative partners to which a firm could switch.

Through past experiences the firm gains detailed information on the partner's competence and behaviour. If a firm can look back on positive experiences with the partner, i.e., the partner has shown to be competent and trustworthy, a firm has reason to place initial trust. A long shadow of the past, combined with positive experiences, reduces the need for contractual commitments. Lorenz (1988) illustrates this with his study on the relations between subcontractors and machinery manufacturers in the region around Lyon, in France. Before manufacturers place larger orders with their subcontractors, they place smaller 'test' orders to build up trust. Other studies have related the shadow of the past to the formality of the contractual arrangement, arguing that partners who know each other well will rely on less formal and less costly contracts (Allen and Lueck 1992: 369-370; Gulati 1995: 95; Lyon 1994: 264). In fact, the two partners use this earlier relation to build up mutual trust (Blau 1964: 94; Ring and van de Ven 1992). A long shadow of the past provides a good basis of information. This information creates an advance on trust and therefore fewer contractual commitments need to be implemented.

Hypothesis 4: The longer a positive shadow of the past, the fewer contractual commitments are used. 
While the shadow of the past provides better information, a long shadow of the future reduces the chance of the partner behaving opportunistically. A long shadow of the future offers periodic and moderate profits over a long time. Moderate but periodical profits will generally outweigh the single short-term profit from opportunistic behaviour. Thus, a long shadow of the future enables the partners to ensure cooperative behaviour by applying 'tit for tat' strategies according to the biblical advice 'an eye for an eye and a tooth for a tooth' (Axelrod 1984). The shadow of the future allows for retaliation to opportunism. Therefore, one would expect that a cooperation which has a long shadow of the future would rely less on contracts. However, a long shadow of the future also implies a long time horizon. If the partners of the cooperation intend to build up a long-lasting relationship, they are likely to design a contract containing more clauses and commitments, because the contract has to cover more possibilities due to the long-term perspective of the relation. Given these two opposing effects, one cannot derive a hypothesis on the main effect of a shadow of the future on contracting. Raub (1996) elaborates on these two effects of the shadow of the future and relates them to the shadow of the past. He argues that a long shadow of the future increases the necessity of implementing more contractual commitments if the partners do not have a shadow of the past. If they can look back at a positive shadow of the past it is likely that certain contractual investments have already been made in earlier contract negotiations. Hence, given a shadow of the future and a shadow of the past the sanctioning threat becomes dominant.

Hypothesis 5: The longer the shadow of the future, the fewer contractual commitments are used, if, and only if, the firms have a shadow of the past.

Another response to opportunism is the termination of the cooperation. An exit threat is only credible if the firm can continue the project either on its own or with an alternative partner. The exit network indicates to what extent alternative partners are available. Thus, having a good exit network will discourage the partner from behaving opportunistically and reduce the necessity for contractual commitments.

Hypothesis 6: The better a firm is embedded in an exit-network, the fewer contractual commitments are used.

The (implicit) threat to terminate a cooperation is one way of ensuring cooperative behaviour from the partner. Another way is based on voice (Hirschmann 1970). Voice threats count on the partner's interest in keeping a spotless reputation as a trustworthy and reliable business partner. Thus, when a firm is able to inform many other parties about opportunistic behaviour of the partner, and these other parties can verify the accusations, the reputation of the partner will be damaged. Similar to the shadow of the future, a firm strongly embedded in a voice network can ruin the partner's future business by damaging that partner's reputation. The difference 
between worse future business prospects due to a shadow of the future and to a strong embeddedness in a voice network rests in the dependency from others. Voice threats only work if other firms indeed reconsider their current and future business with the partner. The possibility of disciplining the partner through voice threats can serve as a substitute for contractual commitments, if the firm is strongly embedded in a voice network.

Hypothesis 7: The better a firm is embedded in a voice network, the fewer contractual commitments are used.

\section{Design and Data Collection}

This study is interested in the mechanisms used to mitigate opportunism within inter-firm relationships. Hence, the appropriate unit of analysis is the inter-firm relationship. Thus, all variables are measured on the level of the cooperation and not at the firm level. To test the hypotheses, data about 92 technology cooperations were gathered. The 92 cases were collected in five Dutch multinationals operating in the electronics, communication, chemistry and food sector. These are the five largest sectors in the Netherlands - in terms of revenues and value added (CBS 1996: 167-168). We collected data on 10-34 cooperations in each of the five multinationals. Collecting a larger number of observations from a few firms increases the amount of effort, and therefore time, required of the participating companies. However, we found that firms were very willing to participate when we explained that, as cases are company-specific analyses, the more we could take from their company, the more beneficial this would be to them than general reports. In each company, the cases were sampled according to the following procedure. After a company had said that they were willing to participate, we met with one or two members of the executive board to plan the data collection within the company. At this meeting, we agreed on the number of cooperation projects, i.e., cases, we would investigate, and then we selected them. All cooperations in the final sample had to satisfy the following two requirements: (1) to reduce problems of retrospective measurement, the cooperation had to have been formed within the last five years; (2) for each cooperation, there had to be one person in the company who could provide all the necessary information. To sample the cases, a 'quasi' stratification on the volume of cooperations and the shadow of the past was applied. First, we asked the management to rank all cooperations (including the unsuccessful and already terminated ones) according to their volume. Half of the cases in each firm were taken from the top of this ranking. In a second step, we determined the shadow of the past for the selected cooperations. If, among the selected cases, the shadow of the past was imbalanced, we balanced the company sub-sample by adding a new or an earlier partner to the cooperations.

We obtained the data by means of written questionnaires and structured interviews with the responsible cooperation managers between May 1994 
and June 1995. During the first appointment with a cooperation manager, the purpose and importance of the research was explained. The interviewer handed out the written questionnaire and made an appointment for an interview. This written questionnaire consisted of 89 statements linked to fivepoint Likert scales measuring all the independent variables, except the volume. At the second meeting, the interviewer collected the written questionnaire and talked to the manager using a highly structured questionnaire. For each case, the interview usually took about 45 minutes and consisted of two parts. In the first part, the volume of the cooperation and further questions on independent variables were addressed. The second part was a detailed analysis of the cooperation contract.

\section{Measurement: Dependent Variables}

Our main dependent variable is the number of contractual commitments given by the partners. To measure this variable, we developed a list of possible contractual aspects in close cooperation with law experts from the Utrecht University Law School. We also discussed this list with two company lawyers specialized in contract law. This list of contractual aspects resembles a (nearly) complete contract for inter-firm cooperations. The fact that none of the 92 contracts contained aspects not mentioned on the list indicates that the list covered all relevant aspects and can be considered as 'empirically' complete. The structured questionnaire guided the interview on the contract as well as our own analysis of the contract and provided us with detailed information on the content. During the data collection it became evident that a more detailed measurement of the different contractual aspects would be very beneficial. Therefore we used an extended version of the questionnaire in the companies $\mathrm{C}$ and $\mathrm{D}$. Consequently, in these two companies, the measurement is based on more detailed information. To minimize possible measurement biases we grouped the different contractual commitments into seven groups (see Table 2). For each of the seven groups, I calculated to what extent the contract contained commitments on this aspect. The average of the commitment group scores is consequently a relative measurement for the contractual commitments, ranging from 0 for contracts with no commitment at all to 1 for contracts with extensive commitments for all contractual aspects.

\section{Measurement: Independent Variables}

The problem potential of a cooperation is measured on three dimensions, namely volume of the cooperation, relation- specific investments and uncertainty. The last mentioned can be divided into external and internal uncertainty. The measurement of the volume of the cooperation includes the year budget plus the man-years assigned to the project. A Kruskal-Wallis test shows that the volume of the cooperations differs significantly between the companies. On average, the cooperations of company A are a bit smaller than those of company B. The measurement of relation-specific investments 
Table 2

Contractual

Aspects and

Related

Commitments
Contractual Aspect Group Commitments related to:

Financial aspects

R\&D costs

Payment

Price and/or cost changes

Methods of cost calculations

Internal management

Monitoring

Allocation of outcomes

Intellectual property

External relations

Conflict resolution
Provision machinery

Joint development / co-makership

Responsibility for spare parts / back-ups

Maintenance responsibility

Up-dating information and / or products

Termination of co-operation

Implementation and structure of committees

Appointing of contact people

Methods of planning

Flexibility of planning

Reporting

Prolongation of co-operation

Termination of co-operation

Control of quality and performance

Methods of quality and performance rating

Access to factories and laboratories

Exchange of employees

Ownership of jointly acquired knowledge

Ownership of jointly developed patents, licences, trademarks, etc.

Non-disclosure of acquired knowledge

Contribution of existing patents

Non-disclosure of contributed knowledge

Escrow clauses

Exclusivity of relation

Obligation to buy / sell offered services and products

Participation of third parties

Restrictions in the choice of partners for other co-operations

Agreements on arbitration Agreements on arbitration rules

Agreements on sanctions in the event of delayed payment Agreements on sanctions in the event of bad quality and performance

is an assessment of the amount of investments in physical, human and social capital that would be worthless if one of the partners terminated the cooperation. Next to direct relation-specific investments, additional factors increasing the (mutual) dependency were considered. There is no evidence that the cooperations within the five companies differ in their specific investments. Technological development and market fluctuations determine the external uncertainly. In general, the cooperations of the companies A 
and D faced more external uncertainty. One possible reason for this result is that the divisions that were investigated in these companies had a much larger R\&D department, indicating that they worked on the edge of new technologies. An analysis of the two sub-variables of external uncertainty, i.e. market uncertainty and technological uncertainty, shows that the difference between the companies are mainly caused by differences in the technological uncertainty. A firm's knowledge and experience concerning the joint project with the cooperation partner determines the internal uncertainty. Thus, indicators of a firm's ability to evaluate and compare potential partners and their performances measure the internal uncertainty, which does not differ significantly between companies.

The social embeddedness of a firm was assessed by four factors. The temporal embeddedness is split into a shadow of the past and the shadow of the future. The measure of the shadow of the past is the time the partners do business with each other weighted by the firm's satisfaction and the intensity of the previous relationships. The Kruskal-Wallis test reveals a significant difference between the companies, caused by company B. First, company $\mathrm{B}$ is the only one to have maintained relations with a partner for more than 50 years. Second, all technology cooperations of company B are with a partner whom they have known from previous business contacts. One reason for this strong stability in contacts might be that $R \& D$ plays a marginal role in this company compared to the other ones. The shadow of the future reflects the expectation of the firm concerning the continuation of the relationship. Unfortunately, data on the shadow of the future are missing for two of the five companies we approached. Therefore, we estimated the shadow of the future for these companies by using information gathered on the course of the cooperation at all five companies (see Appendix 2). While the mean shadow of the future for companies $\mathrm{B}, \mathrm{C}$ and $\mathrm{D}$ is about equal, the future expectations of companies $\mathrm{A}$ and $\mathrm{E}$ have lower means. The number of available alternative partners measures the exit network of a firm. A KruskalWallis test indicates significant differences between the companies. Closer inspection shows that companies A, D and E have smaller exit networks. The reasoning with respect to external uncertainty applies analogously here. The companies mentioned are technology leaders who are interested in gaining partners with a similar level of technological competence. Partners with such competencies are rare, and there are rarely alternative partners. Finally, the voice network is measured by a firm's network overlap with a partner and the reputation of the firm. In the end, two types of control dummies were constructed. First, there is a dummy for each company. Second, we introduce a dummy variable to distinguish between two types of technology cooperations, namely those initiated and managed by the R\&D department and technology cooperations managed by the purchasing department.

Table 3 gives a brief overview of the descriptive statistics of the variables. Furthermore, it presents the $\chi^{2}$ of a Kruskal-Wallis test to examine differences between the firms. Appendix 1 provides more detailed information about the exact formulation of the items used, and, for information, reliability tests are also included. 
Table 3

Descriptive

Statistics of the Used Variables $(\mathrm{N}=92)$

\begin{tabular}{lccc}
\hline Variable & Mean & $\begin{array}{l}\text { Standard } \\
\text { deviation }\end{array}$ & $\begin{array}{l}\text { Kruskal-Wallis } \\
\mathrm{X}^{2(a)}\end{array}$ \\
\hline $\begin{array}{l}\text { Dependent Variable } \\
\text { Commitments }\end{array}$ & .57 & .22 & $12.93^{*}$ \\
& & & \\
Independent Variables & 2.86 & .96 & $24.51^{* *}$ \\
External uncertainty & 2.86 & 1.00 & 7.16 \\
Internal uncertainty & 2.72 & .75 & 5.09 \\
Specific investments & 5.96 & .84 & $28.98^{* *}$ \\
Log volume & 8.86 & 21.85 & $12.23^{*}$ \\
Shadow of the past & 3.81 & 1.02 & $16.12^{* *}$ \\
Shadow of the future & 2.58 & 1.48 & $27.15^{* *}$ \\
Exit network & 2.57 & .76 & $30.45^{* *}$ \\
Voice network & & & \\
& & & \\
Controls & .49 & .50 & \\
Company A & .14 & .35 & \\
Company B & .14 & .35 & \\
Company C & .12 & .33 & \\
Company D & .11 & .31 & \\
Company E & .29 & .46 & \\
Purchase & &
\end{tabular}

(a) Significance level of $\mathrm{X}^{2}$ at $\mathrm{df}=4^{* *}: p<.01 *: p<.05$

\section{Analysis}

\section{Nesting Problems, Preliminary and Specification Analyses}

This study is based on the extensive and detailed information of 92 cooperations. The peculiarity of this data-set is that, on the one hand, its number of observations exceeds the (multiple) case-study research usually carried out in organizational science. On the other hand, the detailed information obtained, for example, on the content of the contract, go far beyond what is typically available from secondary databases with large numbers of observations. However, such medium-sized data-sets require a careful application of statistical methods. One must check whether important assumptions of the applied statistical methods have been violated.

The data-set used consists of 92 cases, nested within five companies. Since the use of the management instrument could be influenced by certain company policies, the observations are not independent of each other. For example, anti-trust laws, which forbid long-lasting and extensive commitments between certain business partners, may effect one company more than another. A common method in dealing with such nesting problems is multi-level analysis (see, e.g., Bryk and Raudenbusch 1992). However, the use of multi-level models is not advisable, if there are only a few focal companies. Therefore, I used fixed-effect models and took the following precautions to deal with possible nesting problems. First, company dummies are included in all analyses to control for company effects on the 
mean. Thus, the coefficients presented are not biased, in the sense that certain companies commit themselves more (or less) than others. Second, the idiosyncrasies of a company may not only influence the mean, but also the variance of the dependent variable, i.e. the assumption of homoscedasticity is violated. For example, the broad use of company-specific standard contracts will reduce the variance of commitments within a company. A Cook-Weisberg test showed that our data do not suffer from heteroscedasticity. The results of the preliminary analyses show that nesting is not a serious problem for the analysis of contractual commitments in this dataset. Furthermore, in additional specification analyses, I also assessed whether certain idiosyncrasies of a company relate to independent variables. Company-specific rules that require the signing of secrecy agreements above a certain volume are an example of an idiosyncrasy that links the volume of a cooperation to a specific commitment. One can check whether this is the case by including the interaction effects between the independent variable and the company dummies. These interactions were insignificant for all variables, except volume. Only in the companies B and $\mathrm{D}$ was a positive interaction between the company dummy and volume observed. The positive relation between volume and commitments is even stronger in the two companies. It is reasonable to use a standard fixedeffect model overall, because the underlying assumptions are not heavily violated.

\section{Results}

All independent variables except the dummies were transformed to $z$-scores, i.e., their mean equals 0 and their variance is 1 . This standardization allows comparison of the coefficients of the variables. Thus, a larger coefficient in absolute terms has a stronger effect on the contractual commitments. Table 4 shows a stepwise analysis. The first model $\mathrm{A}$ is the reference model containing only the control variables. The next model B contains all independent variables measuring the problem potential, allowing an assessment of the explanatory power of standard transaction-cost-economics reasoning. Model $\mathrm{C}$ extends model $\mathrm{B}$ with variables describing the social embeddedness, and, finally, in model $\mathrm{D}$, the effect of past-future interaction is added, to test Hypothesis 5. Before I discuss the effects of the independent variables in detail, I will compare the models presented in Table 4. Model $\mathrm{B}$, which contains the variables of the problem potential, and a highly significant F-value - 4.89 - is a significant improvement on reference model A. Thus, transaction-cost theory delivers a substantial contribution to the explanation of how contractual commitments are used, and model B explains 34 percent of the variance in contractual commitments. In the next model, the impact of social embeddedness is added. By adding the variables of social embeddedness, the variance that can be explained is increased to 40 percent, although the general model is only marginally improved. The F-value for the step from model $\mathrm{B}$ to $\mathrm{C}$ is 1.65 . The consideration of the 
past-future interaction effect in model $\mathrm{D}$ does not improve the model in general terms. The F-value for the step from model C to D is only 0.79 , but the explained variance of model $\mathrm{D}$ is still 40 percent.

The coefficients of model $\mathrm{C}$ test the hypotheses related to main effects, and model D tests the interaction Hypothesis 5. All four dimensions of the problem potential show positive effects. Except for the external uncertainty, these effects are significant. Hence, Hypotheses 1 and 2 are supported. Hypothesis 3 is supported with respect to the internal uncertainty, but not as far as the external uncertainty is concerned. Thus, high potential-problem levels are associated with an extensive use of contractual commitments. Firms adjust their use of contractual commitments to the necessity determined by the incentives and probabilities for opportunism.

The results are mixed, however, for mechanisms based on social embeddedness. Earlier relations with the partner generate initial trust, and, as is shown by the significant negative coefficient of the shadow of the past, reduce the need to enter into commitments. Thus, Hypothesis 4 is supported.

Table 4

Multivariate Analysis of the Commitments (standard errors are robust estimates)

\begin{tabular}{|c|c|c|c|c|c|}
\hline & $\mathrm{H}$ & Model A & Model B & Model C & Model D \\
\hline \multicolumn{6}{|l|}{ Problem Potential } \\
\hline External uncertainty & + & & .018 & .013 & .010 \\
\hline Internal uncertainty & + & & $.039 *$ & $.045^{* *}$ & $.044^{* *}$ \\
\hline Specific investments & + & & $.042 * *$ & $.038 * *$ & $.039 * *$ \\
\hline Log volume & + & & $.062 * *$ & $.059 * *$ & $.058 * *$ \\
\hline \multicolumn{6}{|l|}{ Social Embeddedness } \\
\hline Shadow of the past & - & & & $-.024 * *$ & -.075 \\
\hline Shadow of the future & $?$ & & & -.011 & -.022 \\
\hline Exit-network & - & & & .028 & .031 \\
\hline Voice-network & - & & & $.057 * * *$ & $.056^{* *}$ \\
\hline \multicolumn{6}{|l|}{ Interaction Effects } \\
\hline $\begin{array}{l}\text { Shadow of the past } \times \\
\text { Shadow of the future }\end{array}$ & - & & & & $-.103 *$ \\
\hline \multicolumn{6}{|l|}{ Control Variables } \\
\hline Purchasing technology & & $-.155^{* *}$ & $-.141 *$ & $-.168 * *$ & $-.166 * *$ \\
\hline Company B & & -.056 & $-.144 *$ & $-.198 * *$ & $-.200 * *$ \\
\hline Company $\mathrm{C}$ & & .052 & .057 & -.004 & .018 \\
\hline Company D & & $-.176 * * *$ & $-.210 * * *$ & $-.325 * * *$ & $-.332 * * *$ \\
\hline Company E & & $-.067 *$ & -.049 & $-.136 * *$ & $-.136 * *$ \\
\hline Intercept & & $.647 * * *$ & $-.656 * * *$ & $-.703 * * *$ & $.705^{* * *}$ \\
\hline $\mathrm{N}$ & & 92 & 92 & 92 & 92 \\
\hline F-Value & & $5.14^{* * *}$ & $5.52 * * *$ & $5.60 * * *$ & $6.03 * * *$ \\
\hline $\begin{array}{l}\text { F-Value compared to } \\
\text { previous model }\end{array}$ & & & $4.89^{* * *}$ & $1.65^{*}$ & .79 \\
\hline$R^{2}$ & & .19 & .34 & .40 & .40 \\
\hline
\end{tabular}

$* * * p<.01 ; * * p<.05, * p<.10$ (one-sided testing)

The sign in the second column indicates the expected direction of the relation. Italic coefficients indicate significant contradictory results. 
Mechanisms that are based on a firm's network embeddedness, i.e., ties to partners of the partner and ties to alternative partners, do not reduce the number of contractual commitments entered into by the firm. Hypotheses 6 and 7 on the influence of the voice network and the exit network are not supported. The impact of the voice network is even significantly positive. Hypothesis 5 states an interaction effect. A long shadow of the future has a negative effect on the number of commitments, if there is a shadow of the past. The negative sign of the coefficient in model D of Table 4 supports this hypothesis. Although social embeddedness does not improve the explanation of how contractual commitments are applied between cooperation partners, more specific analysis reveals that social embeddedness matters. The most striking result is that mechanisms based on temporal embeddedness reduce the use of contractual commitments, as expected, while mechanisms related to network embeddedness do not. Finally, the significance of a dummy variable for the type of cooperation, and some company dummy variables, indicates that it was important to control for these effects. The negative sign of the variable 'Purchasing Technology' implies that contracts for joint projects with an R\&D and purchasing component contain fewer commitments than contracts for pure R\&D projects. Apparently, pure $\mathrm{R} \& \mathrm{D}$ projects are more complex, and hence require more contracting, than purchasing relations with an $R \& D$ component. The significance of some company dummies reflects that the number of commitments generally given differs between the companies. Companies A and B include more commitments in their cooperation contracts. Although these two companies are the two largest among the five multinationals investigated, an interpretation of the coefficients in this, or another direction would be highly speculative.

I would like to conclude the results section with some remarks concerning the stability of the findings (I only report the results; see Blumberg 1998 for the underlying analyses). First, a slightly different construction of the dependent variable, for example, a construction that does not group the commitments into seven contractual aspects, does not change the results. All coefficients that had been significant are still significant. Furthermore, I checked whether the imputation of the estimated future for companies A and $B$ influenced the future coefficient by estimating a model which included an interaction effect between the future and an imputation dummy. This variable is insignificant, and therefore the imputation of the estimated future does not influence the analysis.

I then examined whether the model could be improved empirically, by including quadratic and interaction terms for each independent variable, but the inclusion of these terms does not reveal any stable and significant quadratic or interaction effects. Finally, I used the criteria of Belsey et al. (1980) to check if the results are driven by exceptional observations, i.e. outlying cases that have a high leverage (Cook and Welsch distances). Neglecting such cases in re-estimations of the model did not change the direction and significance of the coefficients. Thus, given the results of these specification analyses it can be assumed that the model is well 
specified, and the results are stable. Furthermore, the specification analyses showed that company idiosyncrasies hardly had any influence on the general results.

\section{Discussion and Concluding Remarks}

This paper investigated how firms use contractual commitments to manage their inter-firm cooperation. In line with other more recent empirical studies on transaction cost economics (see, e.g., Gulati 1995; Joskow 1990), the explanadum is not the hierarchy market continuum, but variations in contracts designed for one specific organizational form, inter-firm cooperation. While earlier studies investigated the formality dimension of contracts (see, e.g., Allen and Lueck 1992; Lyon 1994; Palay 1985) or the use of specific clauses in purchasing contracts (Crocker aand Lyon 1984; Leffler and Rucker 1991), this study investigated the commitments made by both partners to mitigate opportunism. Using a more general dependent variable allows more diverse cooperation contracts to be investigated, ranging from long-term contracts for purchasing high technology to joint $R \& D$ contracts.

\section{Remarks with Respect to Transaction Cost Theory}

In detail, the results show clearly that arguments forwarded by transaction cost economics are strongly supported. Problem potential clearly determines the use of contractual commitments. The volume of the cooperation is the most important dimension of problem potential. This finding accentuates the importance of taking volume into consideration when researching interfirm cooperations. Specific investments and the mutual dependency between the partners increase the use of contractual commitments. Thus, the reasoning that the magnitude of specific investments and dependency matters is supported. It is only the results with respect to uncertainty that are less clear. Conversely, that uncertainty is a versatile factor with multiple dimensions comes strongly to the fore in this study. The results concerning external and internal uncertainty coincide with those of Anderson (1988), who observes in her study of vertical integration in distribution channels that internal uncertainty influences how trust-generating mechanisms are used, but external uncertainty does not. The insignificant coefficient of external uncertainty could be the result of two conflicting arguments. On the one hand, in accordance with standard transaction-cost-economic reasoning, a high external uncertainty increases the potential for problems to occur and therefore requires additional contractual safeguards. On the other hand, at high levels of external uncertainty, i.e., within rapidly changing environments, it becomes much more difficult to design appropriate contracts. Hence, mechanisms other than contractual ones will be used to deal with a high external uncertainty. The latter argument applies especially when both partners are equally affected by the risk of uncertainty, or when it is 
not known which partner will be more affected. Other studies on the management of cooperations also reveal ambiguous effects with respect to uncertainty (see, e.g., Walker and Weber 1984, Harrigan 1986). Hence, effects of different kinds of uncertainty should be considered in even more detail (Klein et al. 1990). The distinction between internal and external uncertainty is just one among many. Another useful distinction could follow the dimension of to what extent additional information is able to reduce the uncertainty. For example, given all available information, predictions about the exchange rate between US\$ and $€$ three years from now are still harder to make than predictions about the energy consumption of Dutch households in 2003 .

\section{Remarks with Respect to Social Embeddedness}

The use of mechanisms based on social embeddedness could only be investigated indirectly. It was expected that a firm would rely on its social embeddedness and consequently use fewer contractual commitments. By focusing on the opportunism-mitigating features of contracts, this study neglects other functions of contracts, such as providing a blueprint for co-ordinating partners' activities (Macaulay 1963). Firms that engage in cooperations requiring a lot of co-ordination might write extensive contracts, despite their long shadow of the past and strong network embeddedness. Taking this into account, it becomes more difficult to detect empirically the relationship between social embeddedness and contracting. The analysis shows that only temporal embeddedness has the expected effects; network embeddedness does not. The results presented here are also consistent with the findings of other recent studies on the management of inter-firm relations. Batenburg et al. (1997) investigated information technology purchasing by small- and medium-sized firms. They find the same significant effects for the shadow of the past and future-past interaction, but no direct effect of future in their analysis of 885 transactions. Using the same data, Buskens (1999) investigated the influence of network embeddedness on contractual safeguards. As in this study, network embeddedness was shown to have no significant effect. Rooks et al. (1997) and Buskens (1999) use factory surveys to analyze similar problems. Rooks et al. investigate how much effort purchase managers put into managing purchase transactions specified in various vignettes. Buskens picks up the lemon problem in the used-car market (see Akerlof 1970) and analyses whether American and Dutch students prefer to buy a second-hand car from a dealer with whom they are embedded. In both studies, temporal and network embeddedness have the expected effects.

This, as other studies (see, e.g., Rooks et al. 1997; Lorenz 1988; Acheson 1985, Wilson 1980), focuses on the positive effects of social embeddedness, namely better access to information sources and third-party support in disciplining the partner. Less is said about the possible drawbacks of social embeddedness, one of which is that, despite the benefits of social embeddedness, there could be situations where high levels of it could be disadvantageous: 
1. A high social embeddedness creates a strong community (Casson 1997: Chapt. 4), which restricts the actions of its members. On the one hand, strong communities provide stability and security through shared values and experiences, but, on the other hand, they foster indolence and discourage innovations and adjustments to new developments.

2. Network ties are based on reciprocity (Schrader 1990). Firms that provide information will also expect to receive similar information, if needed. The costs associated with gathering information via network ties consist not only of the collection costs, but also include the costs of obligations to provide information in the future.

3. Firms that are strongly embedded in a network are not only able to damage a partner's reputation, but one's own reputation can also be damaged - probably in an unjustified way. Once gossip is spread, people will not necessarily apply the principle 'in dubio pro reo' to judge the truth of the gossip.

4. If a strong exit network exists, the feasibility of an opportunistic exit increases. On the one hand, a good exit network provides a useful instrument to discipline the partner. On the other hand, the same exit network increases the problem potential, since an opportunistic termination of the alliance becomes feasible. Hence, a good exit network can accentuate the necessity for commitments to discourage opportunistic exit.

The most striking feature of the results with respect to social embeddedness is that mechanisms based on the social structure between two partners work well, while mechanisms relying on the support of social networks do not have the expected effects. Obviously, firms rely on mechanisms that provide direct control of the partner, but they do not trust the effectiveness of indirect mechanisms. An additional consideration in this respect concerns efficacy and, in particular, the efficacy problems of voice threats. Similar to the enforceability problem of contractual instruments, an effective voice threat is one that unambiguously and verifiably communicates the partner's misconduct to third parties. If third parties cannot verify the misconduct of the partner, they will certainly hesitate to turn against that partner. The 'opportunistic' partner then has the option of reducing their own reputational damage by offering apologies. Finally, the intentions and actions taken by the third parties are crucial for the efficacy of voice threat. Third parties may not be willing to contribute their own resources to help to spread the information or they may even use such information strategically to the disadvantage of the 'opportunistic' firm (Williamson 1996: 153-154). Similar problems also arise when third parties are used as information sources to assess a potential partner's competence and trustworthiness. First, it can be difficult to verify the accuracy of the information provided. A second consideration is that third parties may have a hidden agenda and provide information strategically. In the third place, earlier experiences of a third party may not reflect the general or current behaviour of a potential partner. However, it should be noted that the above list of possible drawbacks is just one part of the story. The other part is that firms may not utilize their network embeddedness optimally. Thus, firms 
could manage their inter-firm cooperations more efficiently, if they utilize unused potentials of their network embeddedness.

\section{Appendix}

\section{Construction and Operationalization of the Independent Variables}

Independent Variables, Items

and Subvariables

(Cronbach's $\alpha$ in parentheses)

\section{Independent variable}

External uncertainty

Market uncertainty

$(\alpha=.74)$
Technical uncertainty

$(\alpha=.72)$

$(\alpha=.71)$

Internal Uncertainty
$=($ mean market uncertainty + mean technological uncertainty) / 2

Then we expected large changes in our demand for such co-operations. (5)

Then the changes in our demand for such co-operations were difficult to predict. (5)

Then we expected large fluctuations in the opportunities to form such co-operations. (5)

Then the fluctuations in the opportunities to form such co-operations were difficult to predict. (5)

Then we expected frequent changes in the technical specification of the co-operation. (5)

Then it was highly probable that the technology used in the co-operation would be quickly improved. (5)

Then our company had the necessary knowledge to evaluate the $R \& D$ performance of our partner. (5) Then the evaluation of the R\&D performance of our partner was easy for us. (5)

Then we already had the machinery and laboratory equipment required for the project. (5)

Then we already had the knowledge and know-how required for the project. (5)

Specific Investments

Dependency company $(\alpha=.73)$
$=$ (mean dependency company + specific investments company + dependency partner + specific investments partner) / 4

Then we knew that the termination of the co-operation would result in large revenue losses for our firm. (5) Then we knew that the termination of the co-operation would considerably damage our reputation. (5)

Then this project was very important for our profitability. (5) Then there was a functional dependency between the joint project with this partner and other projects of ours. (5) Then it was very important for us to reach the development goal on time. (5)

Then the flexibility of our partner was of utmost importance for us. (5) 
$+$

Relation specific investments company $(\alpha=.72)$

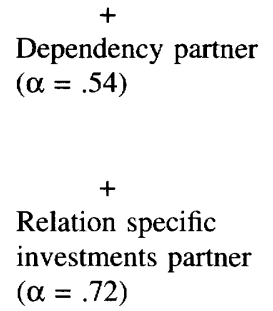

Then we made larger investments in machinery and laboratory equipment, which would be sunk if the co-operation failed. (5)

Then we made larger investments in know-how and knowledge, which would be sunk if the co-operation failed. (5)

Then we made larger investments in building up and maintaining contacts, which would be sunk if the cooperation failed. (5)

Then we knew that a termination of the co-operation would cause larger revenue losses for our partner. (5) Then we knew that a termination of the co-operation would considerably damage the reputation of our partner. (5)

Then our partner made larger investments in machinery and laboratory equipment, which would be sunk if the co-operation failed. (5)

Then our partner made larger investments in know-how and knowledge, which would be sunk if the co-operation failed. (5)

Then our partner made larger investments in building up and maintaining contacts, which would be sunk if the cooperation failed. (5)

Yearly project budget of company

Yearly project budget of partner

man-days per year of company * NLG 200000

man-days per year of partner * NLG 200000

Past

number of years of the relation between the company and partner

weight for quality of relation (5) (range between -1 and

$+1,5)$

weight for the relation intensity (5) (range between .75

and +1.25 )

Future $^{\mathrm{b}}$

Do you expect to have other joint projects with this partner in the future, i.e. after the current project. (5)

Exit Network

Then we had sufficient alternative partners, i.e. we had something to choose. (5)

Voice Network

Then we knew the business partners (customers, etc.) of our partner. (5)

Then the business partners (customers, suppliers etc.) of our partner were also business partners of ours. (5)

$(\alpha=.74)$ sector. (5)

Then we and our partner were members of the same association. (5)

Then it was clear that we would inform our business partners if this partner did not meet his obligations. (5) Then it was clear that our business partners would inform us if this partner did not meet his obligations. (5) 
Then we talked with our business partners about this partner. (5)

Then we informed others about potential partners. (5)

Then we informed others about good partners. (5)

Then this partner had an excellent reputation. (5)

Then our partner was highly visible in our sector. (5)

(5) Item measured on 5-point Likert scale.

a The original items were asked in Dutch and German, the native languages of the respondents.

b The construction described above applies to the Companies B, C, D, and E, but not to Company A. Unfortunately, the shadow of the future was not measured directly in Company A. However, from difference scores about the quality of the relationship at the time of contracting and now, I was able to develop an estimation model that could predict the shadow of the future. This estimation model has an $\mathrm{R}^{2}=0.72$. Thus, the difference scores are reasonable predictors for the shadow of the future.

\section{Procedure to Estimate and Imput Missing Future}

Estimation procedure for the shadow of the future in Companies A and B is based on the pure empirical quality of the indicators.

Step 1 From items describing the relation with the partner at the time of contracting and at the time of the interview, change scores are constructed.

Step 2 These change scores are regressed stepwise backwards on the shadow of the future. The final estimation model has an $\mathrm{R}^{2}$ of 0.85 , resulting in the following estimation equation.

\begin{tabular}{|c|c|c|}
\hline uture & $\begin{array}{r}4.132 \\
-.313 \\
.135 \\
-.226 \\
-.197 \\
.208 \\
.524 \\
.370 \\
.108 \\
-.288 \\
.230 \\
.151\end{array}$ & $\begin{array}{l}+ \\
\text { change in importance of partner as buyer }+ \\
\text { change in importance of partner as supplier }+ \\
\text { change in directorate ties }+ \\
\text { change in joint membership in associations }+ \\
\text { change in acquaintance of partner with firm's network }+ \\
\text { change in acquaintance with the partner's partner }+ \\
\text { change perceived mutual trust }+ \\
\text { change inattitude towards exchanging information }+ \\
\text { change in talking with others about partner }+ \\
\text { change in exchange of employees } \\
\text { change in firm's information policy if partner behaves } \\
\text { opportunistically }\end{array}$ \\
\hline
\end{tabular}

Step 3 Future is estimated with the equation above, and imputted if missing. The correlation between the estimated and the measured future is 0.92 .

* The author wishes to thank Werner Raub, Frits Tazelaar and Jeroen Weesie for their useful remarks and comments. The editor's and the reviewers' comments have considerably improved the argumentation and organization of the paper. This research is part of the PIONIER programme 'The Management of Matches' at ISCORE, Utrecht University, subsidized by NWO (The Netherlands Organization for Scientific Research) under grant number PGS 50-370. The research foundation of the Dutch Association for Purchase Management (NEVI Research Stichting) generously supported the data collection. Substantial rewriting of the paper took place while the author was working on the PIONIER programme 'Business Investment Decisions. The Informed Observer Approach' at the Business Investment Research Centre, Maastricht University subsidized by NWO under grant number 400-10-041. All financial support is gratefully acknowledged. 


\section{References}

Acheson, James M.

1985 'The Maine lobster market: between market and hierarchy'. Journal of Law, Economics, and Organization 1: 385-398.

Akerlof, George A.

1970 'The market for 'lemons': Qualitative uncertainty and the market mechanism'. Quarterly Journal of Economics 84: 488-500.

Allen, Douglas W., and Dean Lueck

1992 'The 'back forty' on a handshake. Specific assets, reputation and the structure of farmland contracts'. Journal of Law, Economics, and Organization 8: 366-376.

Al-Najjar, Nabil I.

1995 'Incomplete contracts and the governance of complex contractual relationships'. American Economic Review (Papers and Proceedings) 85: $432-436$.

Anderson, Erin

1988 'Transaction costs as determinants of opportunism in integrated and independent sales forces'. Journal of Economic Behavior and Organization 9: 247-264.

Axelrod, Robert

1984 The evolution of cooperation. New York: Basic Books.

Barney, Jay B., and Mark H. Hansen

1994 'Trustworthiness as a source of competitive advantage'. Strategic Management Journal 15: 175-190.

Batenburg, Ronald S., Werner Raub, and Chris Snijders

1997 Contacts and contracts. Temporal embeddedness and the contractual behavior of firms. Mimeo. Utrecht University Iscore-paper No. 107, Utrecht

Belsley, David A., Edwin Kuh, and Roy E. Welsch

1980 Regression diagnostics. Identifying influential data and sources of collinearity. New York: Wiley.

Blau, Peter M.

1964/89 Exchange of power in social life. Second printing. New Brunswick: Transaction Publishers.
Blumberg, Boris F.

1998 Management von Technologiekooperationen. Partnersuche und vertragliche Planung. Wiesbaden: Gabler.

Bryk, A.S., and S.W. Raudenbusch

1992 Hierarchical linear models. Applications and data analysis methods. London: Sage.

Burt, Ronald S.

1983 Corporate profits and cooptation. Networks of market constraints and directorate ties in the American economy. New York: Academic Press.

Buskens, Vincent

1999 Social networks and trust. Amsterdam: Thesis Publishers.

Casson, Mark

1997 Information and organization: $A$ new perspective on the theory of the firm. Oxford: Oxford University Press.

CBS (Centraal Bureau voor de Statistiek)

1996 Statistisch jaarboek 1995. Den Haag: SDU.

Chung, Tai-Yeong

1995 'On strategic commitment. Contracting versus investment'. American Economic Review 85: 437-441.

Coase, Ronald

1937 'The nature of the firm'. Economica 4: 386-405.

Coleman, James S.

1988 'Social capital in the creation of human capital'. American Journal of Sociology 94: S95-S120.

Coleman, James S.

1988 Foundations of social theory. Cambridge MA: Harvard University Press.

Contractor, Farok J., and Peter Lorange

1988 'Why should firms co-operate? The strategy and economic basis for cooperative venture' in Cooperative strategies in international business. F. J. Contractor and P. Lorange (eds.), 3-28. New York: Lexington. 
Conybeare, John A.

1989 'The usage of deterrent threats in international trade conflicts' in Perspectives on deterrence. Paul Stein et al. (eds.), 191-210. New York: Oxford University Press.

Crocker, Keith J, and Thomas P. Lyon 1984 'What do facilitating practices facilitate? An empirical investigation of most-favored-nation clauses in natural gas contracts'. Journal of Law and Economics 37: 297-322.

Dixit, Avinash K., and Barry J. Nalebuff

1991 Thinking strategically: The competitive edge in business, politics and everyday life. New York: Norton.

Durkheim, Emile

1893/1973 De la division du travail social, 9th Ed. Paris: PUF.

Flap, Henk D.

1988 Conflict, violence, and loyalty. Bern: Peter Lang.

Ghemawat, Pankaj

1991 Commitment. The dynamic of strategy. New York: Free Press.

Grabher, Gernot, editor

1993 The embedded firm. London: Routledge.

Grandori, Anna, and Giuseppe Soda

1995 'Inter-firm networks: antecedents, mechanisms and forms'. Organization Studies 16/2: 183-214.

Granovetter, Mark S.

1985 'Economic action and social structure. The problem of embeddedness'. American Journal of Sociology 91: 481-510.

Gulati, Ranjay

1995 'Does familiarity breed trust? The implications of repeated ties for contractual choice in alliances'. Academy of Management Journal 38: 85-112.

Harrigan, Kathryn R.

1988 'Strategic alliances and partner asymmetries' in Cooperative strategies in international business. F.J. Contractor and P. Lorange (eds.), 205-226. New York: Lexington.
Harrigan, Kathryn R.

1986 'Matching vertical integration strategies to competitive conditions'. Strategic Management Journal 7: 535-555.

Hart, Oliver D.

1987 'Incomplete contracts' in The new Palgrave. Allocation, information and markets. J. Eatwell, M. Milgate and P. Newman (eds.), 163-179. New York: Newton.

Henderson, James M., and Richard E. Quandt

1980 Microeconomic theory. A mathematic approach. New York: McGraw Hill.

Hirschman, Albert $\mathrm{O}$.

1970 'Exit, voice, and loyalty. Responses to decline in firms, organizations, and states'. Cambridge, MA: Harvard University Press.

John, George, and Barton A. Weitz

1988 'Forward integration into distribution. An empirical test of transaction cost analysis'. Journal of Law, Economics and Organization 4: 337-355.

Joskow, Paul L.

1985 'Vertical integration and long-term contracts. The case of coal-burning electric generating plants'. Journal of Law, Economics, and Organization 1: 33-80.

Joskow, Paul L.

1990 'The performance of long-term contracts. Further evidence from coal markets'. RAND Journal of Economics 21: 251-274.

Klein, Benjamin, R.A. Crawford, and Armen A. Alchian

1978 'Vertical integration, appropriable rents and the competitive contracting process'. Journal of Law and Economics 21: 297-326.

Klein, Peter G., and Howard Shelanski

1995 'Empirical work in transaction cost economics'. Journal of Law, Economics, and Organization 11: 335-361.

Klein, Saul, Gary L. Frazier, and Victor J. Roth

1990 'A transaction cost analysis model of channel integration in international markets'. Journal of Marketing Research 27: 196-208. 
Kreps, David M.

1990 'Corporate culture and economic theory' in Perspectives on political economy. James E. Alt and Kenneth A. Shepsle (eds.), 90-143. Cambridge: Cambridge University Press.

Leffler, Keith B., and Randal R. Rucker

1991 'Transaction costs and the efficient organization of production. A study of timber harvesting contracts'. Journal of Political Economy 99: 1060-1087.

Levy, David T.

1985 'The transaction cost approach to vertical integration. An empirical explanation'. Review of Economics and Statistics 67: 438-445.

Lorenz, Edward H.

1988 'Neither friends nor strangers. Informal networks of subcontracting in French industry' in Trust: Making and breaking cooperative relations. Diego Gambetta (ed.), 194-210. Oxford: Basil Blackwell.

Luhmann, Niklas

1979 Trust and power. Chichester: Wiley.

Lyon, Bruce R.

1994 'Contracts and specific investment. An empirical test of transaction cost theory'. Journal of Economics and Management Strategy 3: 257-278.

Macaulay, Stewart

1963 'Non-contractual relations in business'. American Sociological Review 28: 55-66.

Milgrom, Paul, and John Roberts

1992 Economics, organization and management. Englewood Cliffs, NJ: Prentice-Hall.

Nohria, Nitin, and Robert G. Eccles, editors

1992 Networks and organizations. Structure, form and action. Cambridge MA: Harvard Business School Press.

Oliver, Amalya L., and Mark Ebers

1998 'Networking network studies. An analysis of conceptual configurations in the study of inter-organizational relationships'. Organization Studies 19/4: 549-583.
Ouchi, William G.

1980 'Markets, bureaucracies and clans'. Administrative Science Quarterly 25: $120-142$.

Palay, Thomas M.

1984 'Comparative institutional economics: The governance of rail freight contracting'. Journal of Legal Studies 13: 265-287.

Palay, Thomas M.

1985 'Avoiding regulatory constraints: Contracting safeguards and the role of informal agreements'. Journal of Law, Economics, and Organization 1: 155-175.

Powell, Walter W.

1987 'Hybrid organizational arrangements: New forms or transitional development?'. California Management Review 29: 67-87.

Pucik, Vladimir

1988 'Strategic alliances with the Japanese: Implications for human resource management'. in Cooperative strategies in international business. Farok J. Contractor and Peter Lorange (eds.), 487-498. New York: Lexington.

Quinn, James B., and Frederick G. Hilmer

1994 'Strategische uitbesteding'. Holland Management Review 41: 77-90.

Rasmusen, Eric

1996 Games and information. An introduction to game theory. Oxford: Basil Blackwell.

Raub, Werner

1996 Effects of temporal embeddedness on ex-ante planning under incomplete information. Mimeo. Utrecht University, Iscore Paper-Nr. 87, Utrecht.

Raub, Werner, and Jeroen Weesie

1990 'Reputation and effiency in social interactions. An example of network effects'. American Journal of Sociology 96: 626-654.

Richter, Rudolf, and Eirik Furubotn

1996 Neue Institutionenökonomie. Eine Einführung und kritische Würdigung. Tübingen: Mohr. 
Ring, Peter Smith, and Andrew H. van de Ven

1992 'Structuring cooperative relationships between organizations'. Strategic Management Journal 13: 483-498.

Rooks, Gerrit, Robert Selten, Werner Raub, and Frits Tazelaar

1997 'Samenwerking tussen afnemer en leverancier. Effecten van sociale inbedding op de onderhandelingsinspanning bij inkooptransacties'. Mens \& Maatschappij 72: 352-373.

Schrader, Stephen

1990 Zwischenbetrieblicher Informationstransfer: Eine empirische Analyse kooperativen Verhaltens. Berlin: Duncker \& Humblot.

Snijders, Chris

1996 Trust and commitments. Amsterdam: Thesis Publishers.

Sobrero, Maurizio, and Stephen Schrader 1998 'Structuring inter-firm relationships. A meta-analytic approach'. Organization Studies 19/4: 585-615.

Stafford, Edwin R.

1994 'Using cooperative strategies to make alliances work'. Long Range Planning 27 (June): 64-74.

Walker, Gordon, and David Weber

1984 'A transaction cost approach to make-or-buy decisions'. Administrative Science Quarterly 29: 373-391.

Weesie, Jeroen, and Werner Raub

1996 'Private ordering: A comparative institutional analysis of hostage games'. Journal of Mathematical Sociology 21: 201-240.
White, Halbert

1980 'A heteroscedasticity-consistent covariance matrix estimator and a direct test for heteroscedasticity'. Econometrica 38: 817-838.

Williamson, Oliver E.

1975 Markets and hierarchies: analysis and anti trust implications. New York: Free Press.

Williamson, Oliver E.

1983 'Credible commitments: Using hostages to support exchange'. American Economic Review 73: 519-540.

Williamson, Oliver E.

1985 The economic institutions of capitalism. New York: Free Press.

Williamson, Oliver E.

1991 'Comparative economic organization. The analysis of discrete structural alternatives'. Administrative Science Quarterly 36: 269-296.

Williamson, Oliver E.

1993 'Calculativeness, trust and economic organization'. Journal of Law and Economics 36: 453-486.

Williamson, Oliver E.

1996 The mechanisms of governance. New York: Oxford University Press.

Wilson, James A.

1980 'Adaption of uncertainty and small numbers exchange. The New England fresh fish market'. Bell Journal of Economics 4: 491-504. 